brazilianpoliticalsciencereview

ART I CLE

\title{
The Capital Mistake: Local Information and National Electoral Reforms*
}

\author{
Valentín Figueroa \\ Universidad de San Andrés, Argentina
}

\begin{abstract}
Electoral reforms are often portrayed as strategic decisions by rational actors. However, expectations about the electoral consequences of reforms are not always realized ex post. I argue that these strategic mistakes occur because of information failures. Even though electoral reforms are decided at a national level, electoral information is geographically concentrated at a local level, where elections take place. At the time of reforms, members of the National Congress need to gather local level information. When deciding whether to support or oppose reforms, information varies across actors. Well-informed actors make better decisions, while ill-informed actors end up as "strategic fools". A statistical analysis of the Argentine electoral reform in 1912 supports my theoretical expectations.
\end{abstract}

Keywords: Electoral information; information failures; regime choice; uncertainty.

lectoral reforms that are voted for in Congress are not always
favorable to all actors who support them. What makes some actors "strategic fools" (ANDREWS and JACKMAN, 2005)? Why do some Members of Congress (MCs) support reforms that are not beneficial for them or block reforms that have no consequences over their electoral performance?

(*) http://dx.doi.org/10.1590/1981-38212015000300019

For replication, see bpsr.org.br/files/archives/Dataset_Figueroa.html. 
This issue is ontologically prior to regime choice. A theory of the process by which beliefs about future electoral performance are consolidated might shed light on electoral reform studies as a whole and especially on those which conceive electoral reforms as strategic decisions.

Following an initial interest in the political consequences of electoral systems (AMORIM NETO and COX, 1997; BAWN and ROSENBLUTH, 2003; MYERSON, 1993; PERSSON and TABELLINI, 2003; PERSSON, TABELLINI and TREBBI, 2003; PERSSON, ROLAND and TABELLINI, 2007), a more recent line of research has focused on the causes of electoral reforms. It is now widely accepted that electoral reforms are strategic decisions by rational actors (BOIX, 1999; CALVO, 2009; CUSACK, IVERSEN and SOSKICE, 2007; 2010; KREUZER, 2010; ROKKAN, 1970).

However, even when electoral system choices are strategic, uncertainty ${ }^{1}$ frequently makes success or failure almost impossible to predict (ANDREWS and JACKMAN, 2005). While deciding whether to support or oppose electoral reforms, strategic actors must assign reelection probabilities to a finite set of alternative scenarios; this makes information highly valuable. Sometimes information is easily available and evenly distributed among actors. In fact, while deciding over the 1912 electoral reform in Prussia, MCs already competed under the new rules in national elections (ZIBLATT, 2008). Nonetheless, this is the exception not the rule. In most cases, information is incomplete, scarce, and unevenly distributed.

We should expect information failures to be higher in large federations, where decision-making takes place in Congress (which is located in the capital city), and electoral information is geographically situated at the local level, where elections take place.

Governors, mayors, police chiefs and administrative agents of the judiciary at the local level are better placed than MCs to acquire information about the electoral consequences of reforms for two reasons. First, they command the administration of electoral fraud (BENTON, 2013; CANTÚ, 2014; LARREGUY, OLEA and QUERUBIN, 2014; LEHOUCQ, 2003; MARTINEZ-BRAVO, 2014; RUNDLETT and

\footnotetext{
${ }^{1}$ Following Lupu and Riedl (2012, p. 1344), I consider uncertainty a matter of degree, and define it as "the imprecision with which actors are able to predict future interactions".
} 
SVOLIK, 2014; SIMPSER, 2013). Second, they have a higher proximity to candidates and organizations of the opposition.

Of course, measuring individual information supply is a challenging taskmainly because information is unobservable. However, the study of a case from before the development of efficient communication systems can facilitate the construction of proxies for information supply. In this article I use the case of 1912 Argentina, and the distance from the capital city and each legislator's district as a proxy for information availability. Clearly, distance could not be considered a valid measure of information supply after the invention of planes ${ }^{2}$ or the internet. The rationale for this is straightforward. A MC in the twenty-first century can be wellinformed about her district, independently of its distance from Congress. However, for an MC in the early-twentieth century, geographical distance was a serious limitation.

As a general argument, I hold that local information is cheaper and more readily available for some MCs than others. Particularly for the chosen case (early twentieth-century Argentina), it is likely that MCs from farther districts suffered from bigger information failures.

One way the MCs can compensate for their lack of electoral informationin the absence of efficient communication systems-is to travel to their districts. This demands their absence from congressional floor-meetings and committee work. Absences from Congress also result in informational loss-at the national level-but this is compensated by more valuable local information. Furthermore, for multimember districts, allied MCs benefit from informational economies of scale and share district-specific information among themselves (through conversation, either explicitly or informally). At the time of electoral reforms, wellinformed actors make better decisions, and have a lower probability of being "strategic fools".

I test this theory using data on a crucial case: early twentieth-century Argentina, a large federation with underdeveloped communication and transportation systems that underwent an electoral reform in 1912. Members of the House of Representatives were elected in each of the 14 provinces and the capital city. Districts were multimember and MCs were elected under majoritarian

\footnotetext{
${ }^{2}$ I thank a BPSR reviewer for this observation.
} 
rules in closed party lists. In November 1911, they voted to reform the electoral law from majoritarian rule to incomplete list (lista incompleta). This established that parties should nominate fewer candidates than seats being filled (two-thirds). The remaining seats were awarded to the first minority ${ }^{3}$. The enactment of this law was followed by the collapse of the Partido Autonomista Nacional (PAN), which had ruled the country since 1880 .

A statistical analysis of legislative activity and floor-meetings in the Argentine Congress (1900-1912) supports my theoretical expectations. In order to gather local information, MCs representing districts farther from Buenos Aires requested more permits for absence from congressional sessions. MCs from bigger districts-with more representatives-had a lower probability of being absent, except for the one year when districts became single-member (1904). In addition, MCs from distant districts missed more floor-meetings on the discussion of the electoral reform of 1912. For MCs with strong local ties the effect of distance was even greater. Finally, MCs from farther districts had a higher probability of being "strategic fools" after the 1912 reform, except when they missed floor-meetings to gather local information.

The rest of the article is structured as follows. The first section discusses previous accounts of regime change miscalculations. The second section presents the main argument and derives five observational implications. The third section tests the theory using information on 1900-1912 Argentina. Finally, the fourth section concludes the article and proposes areas for further research.

\section{Endogenous electorall rules}

Ever since Duverger's $\mathrm{Law}^{4}$, electoral systems have been regarded as important variables for explaining a plethora of phenomena, including party system configurations (AMORIN NETO and COX, 1997; COX, 1997), accountability (MYERSON, 1993), political violence (WILKINSON, 2004), redistribution (IVERSEN and SOSKICE, 2006), economic policy (PERSSON and TABELLINI, 2003; PERSSON,

\footnotetext{
${ }^{3}$ Lista incompleta is functionally similar to PR, as it represents a shift away from winnertakes-all electoral rules. However, PR was against constitutional rules. Possibly, lista incompleta was a way to make electoral rules more proportional without a constitutional reform that would require $2 / 3$ of the votes in Congress.

${ }_{4}$ Duverger's Law establishes that winner-takes-all electoral rules encourage two-party systems. See Riker (1982).
} 
ROLAND and TABELLINI, 2007), corruption (PERSSON, TABELLINI and TREBBI, 2003), partisan composition of governments (TAAGEPERA and SHUGART, 1989), and government spending (BAWN and ROSENBLUTH, 2003), among others.

A second line of inquiry has focused on the causes of different electoral systems. At the core of these studies was the insight that electoral rules were changed strategically. A pioneer in this field, Rokkan (1970) argued that proportional representation (PR) rules in Continental Europe were established by parties willing to protect their positions by including potentially dangerous excluded political groups. In a similar vein, Boix (1999) showed that PR was a measure against an imminent "socialist threat". Later, studies showed that electoral reforms responded to strategic interests despite the absence of a strong socialist party (CALVO, 2009).

However, actors were often wrong about the consequences of electoral reforms. Instead of increasing-or preserving-their electoral competitiveness, reforms frequently resulted in seat loss and even defeat in general elections. This fact has led some scholars to question the endogeneity of electoral institutions (BIRCH, 2003; SCHVETSOVA, 2003).

Others constructed theories to explain seat loss after electoral reforms. Two broad theoretical families have tried to account for these "mistakes". The first claims that any kind of anticipation of electoral consequences is fundamentally impossible because of an extreme lack of information (ANDREWS and JACKMAN, 2005). More recent accounts argued that seat losses under reformed rules was a tactical move by powerful ruling parties concerned about regime stability (BARZACHKA, 2014).

Still, arguments about incomplete information are silent on the fact that uncertainty is a matter of degree and that good-quality information might vary across actors. Furthermore, explaining seat loss after electoral reforms as strategic decisions must necessarily portray parties as coherent units, without space for individual indiscipline. Even considering that reforms would benefit the stability of the regime, why would individual actors who will be damaged by reforms support them?

The theory developed in this article, and extensively described in the following section, has two advantages vis-à-vis previous accounts of regime choice 
miscalculations. First, it explains why some actors made better choices than others. Instead of depicting the whole ruling elite as "strategic fools", it focuses on individual actors who support or oppose reforms. In this sense, it treats individual actors, and not parties as a whole, as strategic. Second, instead of assuming extreme information scarcity, the theory explains why information was asymmetrically distributed among actors.

\section{Electoral reforms: national decisions with local information}

Electoral rules are changed by strategic national actors. To increase their certainty about the effects of electoral reforms and behave strategically, they require information. However, even though electoral reforms are national decisions, information about their expected consequences lies at the local level, where elections take place.

In large federations, MCs are elected in subnational districts. Once elected, they are incorporated to the National Congress, which is often located at the country's capital city. When deciding on important matters, strategic MCs must rely on local allies for information gathering.

Electoral oligarchies in the nineteenth and early twentieth centuries were usually ruled by elite parties. These parties were characterized by the fusion between the party on the ground and the party in public office (KATZ, 2002).

Local office holders, like governors, mayors and police officers, have better information than MCs for two reasons. First, they execute electoral fraud. The local character of electoral fraud has been documented by recent studies (BENTON, 2013; CANTÚ, 2014; LARREGUY, OLEA and QUERUBIN, 2014; LEHOUCQ, 2003; MARTINEZ-BRAVO, 2014; SIMPSER, 2013) and shown to generate major coordination problems on the national sphere (EDMOND, 2013; RUNDLETT and SVOLIK, 2014). By virtue of conducting fraud and electoral mobilization, local agents are in a better position to predict the consequences of changes in electoral rules. In fact, in a recent paper, Zarazaga (2014) showed that political brokers are the main source of electoral information that candidates and incumbents have; it is their monopoly over electoral information that renders brokers indispensable. Second, political operators at the local level are closer to opposition candidates. They have better information regarding the opposition's plans, their electoral 
mobilization capacity, and therefore, their prospects for electoral competitiveness under modified rules.

When modern means of communication are not highly developed, information transmission is mainly personal. Written or telephonic communication might work as an imperfect substitute, but, overall, personal interaction should result in reduced misunderstandings and more effective agreements.

In the light of important national decisions and a lack of high-quality communication technology and information, national MCs face two options for information gathering. They can either personally travel to their districts to meet with their political allies and gather information on important matters, or they can rely on information supplied to them by national political allies. Subnational allies at Congress should share information with fellow co-partisans either in an organized manner or informally, through conversation.

The number of local allies at Congress varies with district magnitude. The MCs elected in single-member districts should have fewer allies at the national level than those elected in multimember ones. This leads to the first two observational implications of the theory: (H1) personal information gathering should be more difficult for MCs elected in multimember subnational districts, and (H2) the quality of strategic decisions should increase with district magnitude.

Considering that communication systems are underdeveloped, MCs that demand local level information must personally travel to their districts, missing committee work and floor meetings at Congress. However, absence from their normal legislative activity is a Damocles' Sword. While increasing their access to local information, legislative absence also lowers their levels of national level information and also their time for the consolidation of national agreements or alliances. Nevertheless, as elections take place in subnational districts, local information should be more valuable and result in better choices.

Three more observational implications can be derived from this argument. First, (H3) MCs from districts farther away from the capital city should have a higher probability of being absent in a given year and also during floor meetings to discuss important bills. On average, they should also make worse strategic choices (H3A). Second, (H4) legislative absence should be associated with worse strategic 
decisions. Third (H5), the positive effect of absence on the quality of strategic decisions should hold for MCs that represent districts that are more distant from the capital city.

\section{Assumptions}

The theory presented above has two strong assumptions, which are made explicit to clarify the argument and facilitate falsification. First, the behavior of MCs in Argentina's competitive authoritarianisms is mostly unrelated to popular demands. In this scenario, they primarily focus on their prospects for reelection and the maintenance of their political alliances. Even though this assumption might not hold for parties as a whole, because they might accept tactical seat losses for the sake of regime stability (BARZACHKA, 2014), it should hold for MCs who do not mind the maintenance of their parties' rule independently of their personal maintenance of political power. When their electoral success is not dependent on popular support-as is the case in electoral authoritarianism-MCs should not be responsive to popular demands (in the empirical section below, I relax this assumption). The second assumption is that district-specific information about elections is unknown to authorities of other districts. As information is valuableand costly-political operators shouldn't share it with operators from other districts. Sharing information with others would render them less valuable for MCs at the national level, and consequently, they have an interest in monopolizing that information.

\section{Data and results}

In this section, I describe the case and test all five hypotheses presented above using data on congressional activity in Argentina from 1900 to 1906 and the floor meetings and roll call vote of each MC in the electoral reform of 1912.

\section{The case: Argentina, 1900-1912}

The MCs in Argentina were elected directly in 15 subnational districts-14 provinces and the city of Buenos Aires. Districts were multimember, but magnitude varied according to its population, and the political power governors had to ensure or block changes in representation in Congress after population 
shifts. Elections were held every two years to renew the lower chamber by onehalf each time. In each district, candidates competed in closed party lists under winner-takes-all electoral rules (lista completa). These rules generated strong majoritarian biases. For example, if a list in the biggest province, Buenos Aires, received 51 per cent of valid votes, it got all 15 seats in the lower chamber.

Electoral intimidation was frequent and practiced by all political factions (SABATO, 2004). It was carried out at the local level by the state's administrative infrastructure and without logistical support from economic elites (HALPERÍN DONGHI, 1992, 2007; HORA, 2001). At the day of elections, the police, judges and the National Guard mobilized voters in favor of incumbent candidates (HORA, 2001).

Once elected, MCs had to move to the city of Buenos Aires and attend committee work and floor meetings. When discussing important bills, floor meetings were held (approximately) every two days. Bill sponsorship, however, was low. On average, in the period between 1900 and 1912, each MC sponsored 0.8 bills a year 5 .

Written communication to and from the city of Buenos Aires was common. With a population of 1.36 million $^{6}$, the city received more than 98 million letters and sent over 127 million in 19117. It also received nearly one million telegrams and sent 725 thousand $^{8}$. However, telephonic communication was far less common. The leading telecommunications company-Compañía Unión Telefónica-had little over 26,000 clients in 1911 and its first competitorCompañía Cooperativa Telefónica-had around 7,0009.

\section{Absences to congressional activity}

MCs had to officially request permission if they wanted to travel outside the city of Buenos Aires or momentarily suspend their congressional activity. There were two legal venues for soliciting these permits, Pedido de Licencia and Pedido de Permiso, but they were functionally identical. All permit requests were

5 Catálogo de Expedientes Legislativos (1900-1912) and Nómina Oficial de Diputados (1900-1912).

6 Anuario Estadístico de la Ciudad de Buenos Aires, 1910-1911, p. XLII.

7 Anuario Estadístico de la Ciudad de Buenos Aires, 1910-1911, p. 345.

8 Anuario Estadístico de la Ciudad de Buenos Aires, 1910-1911, p.356.

9 Anuario Estadístico de la Ciudad de Buenos Aires, 1910-1911, page 361. 
presented as table motions (moción sobre tablas) and scheduled on the current session. As noted by Calvo (2014), table motions in the Argentine Congress should not be confused with a 'motion to table' in the US Congress, which is a request to kill debate on a given issue or bill.

License requests sometimes included a brief justification, but generally they did not, as it is shown in Table 01. In the statistical analysis, I focus on unjustified license requests only. I, therefore, exclude those requests due to illness or the need to travel abroad (situations wherein they most probably were not able to gather local information).

Table 01. MCs on leave, 1900-1906

\begin{tabular}{ccccc}
\hline \multirow{2}{*}{ Document } & \multicolumn{4}{c}{ Submitted justification for absence } \\
& Total & Health & $\begin{array}{c}\text { Travelling } \\
\text { abroad }\end{array}$ & Not specified \\
\hline License (Pedido de Licencia) & 136 & 34 & 4 & 93 \\
Permit (Pedido de Permiso) & 23 & 2 & 0 & 21 \\
Num. Obs. & 159 & 36 & 4 & 114 \\
\hline
\end{tabular}

Source: Catálogo de Expedientes Legislativos (1900-1906).

The duration of requested licenses varied. Among the 114 requests with unspecified justifications, I could only find the duration of licenses for 90 cases $(24$ were missing). The duration of requested licenses had a mean of 25.3 days, a standard deviation of 28.1 days, and varied between 03 days and half a year. Long licenses were rare, and most lay between 3 and 50 days ${ }^{10}$. Figure 01 presents a histogram with the distribution of license duration.

If legislative absence is a good proxy for gathering local information, MCs from farther districts should request more licenses in a given year. Accordingly, if same-district MCs share local information among them, the probability of requesting a license in a given year should decrease with district magnitude.

In order to test H1 and H3, I built a dataset of all MCs from 1900 to 1906, with yearly observations on their license requests from Catálogo de Expedientes Legislativos and Nómina Oficial de Diputados, supplied online by the Archive of the National Congress ${ }^{11}$. I excluded those MCs who died, or those who joined the chamber as substitutes.

\footnotetext{
10 Catálogo de Expedientes Legislativos (1900-1906).

11 Raw data for replication is available online, on the archive's webpage: www.archivodiputados.gob.ar.
} 
Each MC year is an observation, and the dependent variable is dichotomous and takes the value of 1 if the MC requested a license at least once that year. As independent variables, I include the natural logarithm of the distance between the capital city of his district and the city of Buenos Aires, measured in kilometers. I also include the variable magnitude, which measures the number of seats his district has in Congress. The model was estimated by ordinary least squares (OLS), and includes fixed effects by year of election, year, and previous legislative experience. Results are presented below, in Table 02.

Figure 01. Duration of requested licenses, 1900-1906

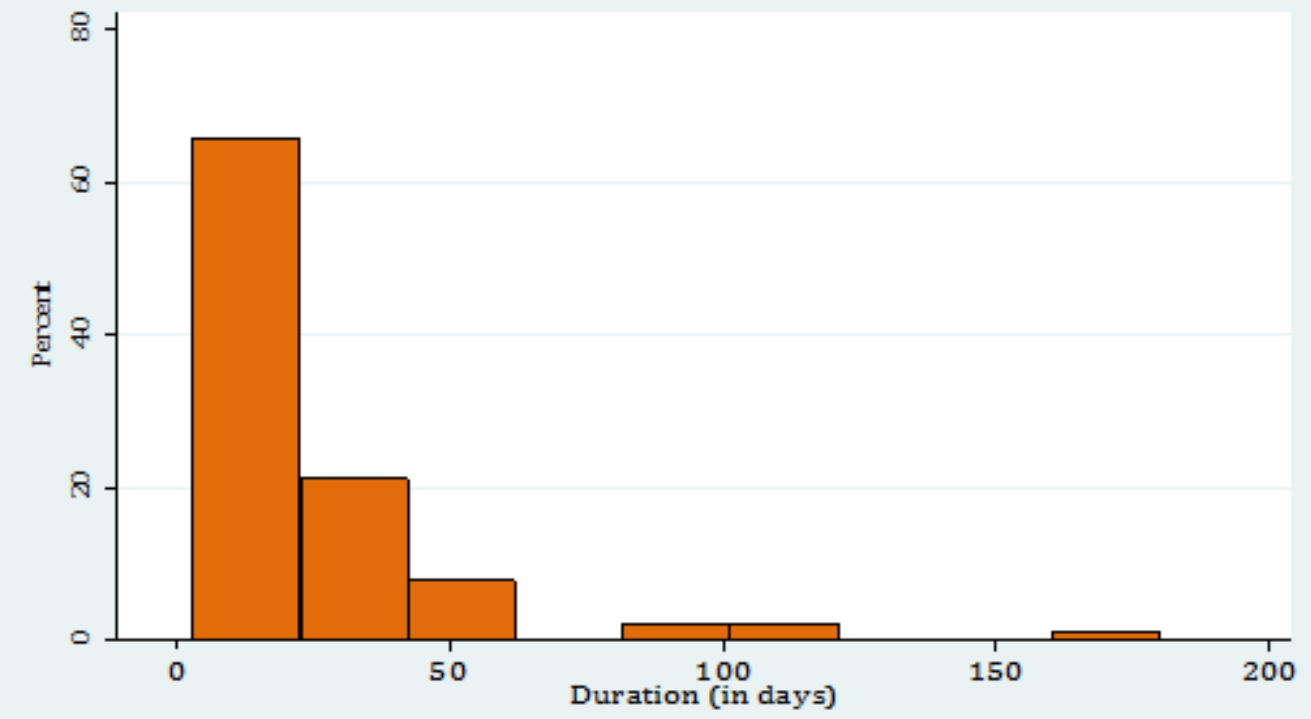

Source: Catálogo de Expedientes Legislativos (1900-1906).

As expected from $\mathrm{H} 3$, on average, and everything else held equal, MCs elected in districts farther from the city of Buenos Aires had a higher probability of submitting an unjustified license request in a given year. Also as expected from $\mathrm{H} 1$, license requests decrease with district magnitude.

Model 02 exploits a shock to district magnitude that can be presumed exogenous in a congressional absence regression. In 1902, Congress enacted an electoral reform that replaced multimember districts by 120 single-member winner-takes-all districts. The rule was applied only in the election of 1904, and was soon suppressed by the government of President Manuel Quintana in 1905 (PEREYRA, 1999; PRIVITELLIO, 2006). Magnitude has no effect over congressional licenses for MCs elected that year. This finding increases our confidence in the fact 
that it is magnitude, and not unobserved provincial characteristics, which affects the probability of soliciting a license.

Table 02. Distance, co-partisans and licenses - 1900-1906

\begin{tabular}{ccc}
\hline & $\begin{array}{c}\text { Model 1 } \\
\text { On leave }=1\end{array}$ & $\begin{array}{c}\text { Model } 2 \\
\text { On leave }=1\end{array}$ \\
\hline Log distance & $.009^{* *}$ & $.009^{* *}$ \\
& $(.004)$ & $(.004)$ \\
Magnitude & $-.003^{* * *}$ & $-.004^{* * *}$ \\
& $(.001)$ & $(.001)$ \\
Election = 1904 & & $.004^{*}$ \\
magnitude & & $.002)$ \\
Year of election FE & Yes & Yes \\
Year FE & Yes & Yes \\
Experience FE & Yes & Yes \\
Num. Obs. & 765 & 765 \\
R2 & .08 & .09 \\
Estimation & OLS & OLS \\
\hline
\end{tabular}

Source: Dataset_Figueroa.

Note: MCs who died or joined the chamber as substituted were excluded from the sample. (Robust standard errors in parentheses). ${ }^{*} \mathrm{p}<0.1,{ }^{* *} \mathrm{p}<0.05,{ }^{* * *} \mathrm{p}<0.01$.

The results support my theoretical expectations. MCs from farther districts must request licenses from Congress in order to gather local-level information. Accordingly, they can also rely on information provided to them by same-district allies, allowing them not to miss committee work and floor meetings.

\section{Electoral reforms and information}

Information is most valuable before voting important electoral reforms. As I have argued, when deciding whether to support or oppose changes in electoral rules, MCs have to make an educated guess on the consequences of the electoral reform over their electoral competitiveness before voting.

After being elected president in 1910, Roque Sáenz Peña sent a bill to Congress proposing a reform on the electoral system ${ }^{12}$. The bill intended to make the vote secret and mandatory for all literate citizens. It also proposed the modification of electoral rules from lista completa to lista incompleta. This modification would decrease the majoritarian bias of the old electoral rules, allowing for a minority party to win one-third of the disputed seats. In order to

12 For a historiographical account of Sáenz Peña's reform bill, see Botana (1985) and Castro (2012). 
make strategic decisions, MCs needed local information about the predictable consequences of the reform on their electoral competitiveness.

There were seven floor meetings before the lista incompleta was voted nominally on November 24, 1911. MCs were often absent from the plenary during the discussion of the bill. Eight MCs were on leave during all meetings. Others were present in some meetings and absent from others. Absences without being on license could be either notified in advanced (con aviso) or not (sin aviso).

In order to retest $\mathrm{H} 1$ and $\mathrm{H} 3$ under conditions of higher information demand, I built a dataset consisting of 649 MC meeting observations. The dependent variable takes the value of 1 if the MC was absent in a given session (either having notified in advanced or not). Absences were computed as they appear in the congressional minutes ${ }^{13}$.

As independent variables, I include the logarithmic transformation of distance, and also district magnitude. To further test the importance of local information, I also include an interaction between distance and a dummy that takes the value of 1 if the MC had strong local ties. On average, MCs with stronger local ties should demand more local information than others. The proxy I use for local ties is having been elected in the election of 1904. As I mentioned before, MCs elected in 1904 had to compete in single member districts. I assume that having won in this election is a proxy for stronger alliances at the municipal level.

Models were estimated by OLS and include fixed effects by previous legislative experience and congressional session. Results are presented in Table 03.

As expected, on average and ceteris paribus, MCs from districts farther away from the capital city had a higher probability of being absent on a given session. As I show in Model 04, the effect of distance is even bigger for MCs, which we can presume have stronger local ties. Unexpectedly, district magnitude is not statistically significant, and its effect is approximately zero. As I show in the multinominal logistic model (Model 06), notified and not notified absences might follow a different pattern, since only distance is statistically significant for explaining not notified absences.

13 For replication, raw data is available on Diario de Sesiones de la Cámara de Diputados, from November 06-24, 1911. 
Table 03. Absentism from floor meetings on electoral reform

\begin{tabular}{|c|c|c|c|c|c|}
\hline & \multirow{2}{*}{$\begin{array}{c}\text { Model } 03 \\
\text { Absent }=1\end{array}$} & \multirow{2}{*}{$\begin{array}{l}\text { Model } 04 \\
\text { Absent= } 1\end{array}$} & \multirow{2}{*}{$\begin{array}{l}\text { Model } 05 \\
\text { Absent= } 1\end{array}$} & \multicolumn{2}{|c|}{ Model 06} \\
\hline & & & & Notified & $\begin{array}{c}\text { Not } \\
\text { notified }\end{array}$ \\
\hline Log & $.04^{* * *}$ & $.04^{* * *}$ & .02 & $.25^{* *}$ & $.27^{* * *}$ \\
\hline Distance & $(.01)$ & $(.01)$ & $(.07)$ & (.11) & $(.10)$ \\
\hline $\begin{array}{c}\text { Local ties X } \\
\text { Log } \\
\text { Distance }\end{array}$ & & $\begin{array}{l}.26^{* *} \\
(.13)\end{array}$ & $\begin{array}{l}.26^{* *} \\
(.13)\end{array}$ & $\begin{array}{c}1.84^{*} \\
(1.01)\end{array}$ & $\begin{array}{c}.53 \\
(.69)\end{array}$ \\
\hline Local ties & & $\begin{array}{l}-1.7^{*} \\
(.92)\end{array}$ & $\begin{array}{l}-1.7^{*} \\
(.92)\end{array}$ & $\begin{array}{l}-11.8^{*} \\
(7.03)\end{array}$ & $\begin{array}{l}-2.80 \\
(4.71)\end{array}$ \\
\hline Magnitude & & & $\begin{array}{c}-.00 \\
(.00)\end{array}$ & & \\
\hline $\begin{array}{c}\text { Experience } \\
\text { FE }\end{array}$ & Yes & Yes & Yes & & \\
\hline $\begin{array}{c}\text { Floor } \\
\text { Meeting FE }\end{array}$ & Yes & Yes & Yes & & \\
\hline Num. Obs. & 694 & 694 & 694 & & \\
\hline R2 & .07 & .08 & .08 & & \\
\hline Estimation & OLS & OLS & OLS & Multino & nal Logit \\
\hline
\end{tabular}

Source: Dataset_Figueroa.

Note: the sample excludes $08 \mathrm{MC}$ who were on leave during all sessions (Bengolea, Bonifacio, Candioti, Gomez, Gonnet, Lopez, M.E, Ortiz and Revilla). Robust standard errors in parentheses. ${ }^{*} \mathrm{p}<0.1,{ }^{* *} \mathrm{p}<0.05,{ }^{* * *} \mathrm{p}<0.01$.

\section{Strategical fools? Information and "good choices"}

In this section, I test hypotheses $02,3 \mathrm{~A}, 04$, and 05 . As I mentioned before, less-informed MCs should make worse strategic decisions when deciding whether to support or oppose electoral reforms.

In order to test the hypotheses, I built another dataset with observations on the way each MC voted for the lista incompleta reform as it appears in the Congressional Minute of November 24, 191114. The dependent variable takes the value of 1 when the MC was correct when voting for the reform. I use a narrow definition of "correct strategic choice".

A vote was considered correct when:

a) The MC supported the reform and won the next election.

b) The MC opposed the reform and lost the next election.

The vote was considered incorrect when:

a) MC supported the reform and list the next election.

b) MC opposed the reform and won the next election.

${ }^{14}$ For replication, raw data is available at: Diario de Sesiones de la Cámara de Diputados del 24 de Noviembre de 1911, page 338. 
It should be noted, however, that this variable can only capture effective reelections or defeats. It might also be the case that a candidate could have lost the following election irrespective of electoral rules. Furthermore, the reform might have increased the odds of being elected for a losing candidate or decreased the odds of being elected for a winning candidate ${ }^{15}$. This is a common problem in the existing literature on the consequences of regime transitions and especially in papers that deal with strategic considerations as intentional causes. Andrews and Jackman (2005), for example, use information on effective party seat loss to support the notion than transitions are unfavorable to the incumbent party under conditions of uncertainty. Ideally, we should compare the performance of each individual candidate under different sets of rules, but this is fundamentally impossible.

However, there is a growing historiographical consensus on the fact that the electoral reform of 1912 was an episode of elite autonomy, virtually disconnected to any kind of social or electoral pressure from other parties (CASTR0, 2012). In this sense, a major change in the electoral competitiveness of MCs was not a foreseeable outcome in the absence of an electoral reform (at least not in the short term). Assuming this is true, the codification of the dependent variable should be less problematic; probabilistically, it shouldn't be an overstatement to hold that MCs who supported the reform and won made a better decision than those who supported it and lost.

Nevertheless, as a robustness check in a second analysis, I restrict the sample to those MCs who were in the chamber of 1912 by virtue of being reelected. I therefore only consider those MCs for whom reelection was a conceivable expectation. This test is particularly strict, because a reduced number of observation ( $28 \%$ of the sample, $\mathrm{N}=27$ ) mechanically enlarges standard errors, favoring the null hypotheses.

The model includes four independent variables. The first is the logarithmic transformation of the distance between the capital city and the MC's district (H3A). The second variable is the average number of sessions that the MC was absent (H4). The third is the district magnitude (H2). The last independent variable is an interaction term between distance and average absences (H5).

15 I thank a BPSR reviewer for this observation. 
Models were estimated by OLS and are presented below, in Table 04 . In models $08,09,11$ and 12 , I include a control for congruence with the president, and it takes the value of 1 if the MC was elected to Congress after the election of the president (in 1910) and 0 otherwise. This control is intended to account for ideological preferences on the reform bill. In models 08 and 11, I include provincial fixed effects to control for interest group pressure at the local level ${ }^{16}$. As distance and magnitude are invariant within districts, they are excluded from these two models.

Table 04. Information and good choices

\begin{tabular}{ccccccc}
\hline & $\begin{array}{c}\text { Model 07 } \\
\text { Correct (excludes abstentions) }\end{array}$ & $\begin{array}{c}\text { Model 08 } \\
\text { Correct }\end{array}$ & $\begin{array}{c}\text { Model 09 } 11 \\
\text { (abstention }=\end{array}$ & $\begin{array}{c}\text { Model } 12 \\
\text { (ex) }\end{array}$ \\
\hline Log distance & $-.08^{* * *}$ & & -.04 & $-.08^{* * *}$ & & $-.05^{*}$ \\
& $(.02)$ & & $(.03)$ & $(.01)$ & & $(.02)$ \\
(Avg) Absent & $-2.5^{* *}$ & $-2.4^{*}$ & $-2.3^{*}$ & $-1.5^{* * *}$ & $-1.1^{* *}$ & $-1.2^{* *}$ \\
& $(1.2)$ & $(1.3)$ & $(1.2)$ & $(.43)$ & $(.55)$ & $(.55)$ \\
Log distance X & $.44^{* *}$ & $.45^{* *}$ & $.43^{* *}$ & $.25^{* * *}$ & $.18^{*}$ & $.20^{* *}$ \\
(Avg) Absent & $(.20)$ & $(.22)$ & $(.20)$ & $(.07)$ & $(.09)$ & $(.09)$ \\
& & & & & & \\
Magnitude & & & $.01^{*}$ & & & .00 \\
& & & $(.00)$ & & & $(.00)$ \\
Year of & & -.18 & $-.21^{* *}$ & & $-.21^{*}$ & $-.22^{* *}$ \\
election & & $(.12)$ & $(.11)$ & & $(.11)$ & $(.10)$ \\
(>1910 $=1)$ & & & & & & \\
Experience FE & No & Yes & Yes & No & Yes & Yes \\
Province FE & No & Yes & No & No & Yes & No \\
Num. Obs. & 77 & 77 & 77 & 94 & 94 & 94 \\
R2 & .14 & .37 & .30 & .17 & .32 & .27 \\
Estimation & OLS & OLS & OLS & OLS & OLS & OLS \\
\hline
\end{tabular}

Source: Dataset_Figueroa.

Note: The sample excludes MCs who were absent in all sessions, including the day of the nominal vote, and also those who died before the first election. (Robust standard errors in parentheses). ${ }^{*} \mathrm{p}<0.1,{ }^{* *} \mathrm{p}<0.05,{ }^{* * *} \mathrm{p}<0.01$.

As I have argued before, I expect distance to have a negative impact on the probability of being correct (H3A). First, MCs from farther districts have less information than others. My second expectation is for absences to have a negative impact on the quality of the choice (H4). Even though absence is used to gather local information, it also results in national informational losses. Third, I expect district magnitude to be positively associated with the probability of being correct (H2). District-sharing MCs should share information between them. Finally, I

16 I thank a BPSR reviewer for raising this concern. 
expect the interaction between distance and absences to have a positive impact on the quality of the decision (H5). Since local level information is more valuable than national information, absences should result into increased information for MCs from farther districts ${ }^{17}$.

The first three models exclude abstentions, and the last three treat abstentions as positive votes ${ }^{18}$. As expected, distance has a negative impact on the probability of being correct in almost every model ${ }^{19}$. MCs from farther districts possess less local information on the consequences of the electoral reform. Also as expected, absences to floor meetings also result into worse information and, consequently, worse strategic choices. Furthermore, magnitude is positively associated to the probability of making a correct decision, but statistical significance fades and the coefficient becomes zero when abstentions are treated as positive votes. Finally, the interaction term between distance and average absences shows a positive sign, suggesting that local information gathering helped MCs act strategically.

\section{Robustness}

In this section, I run a series of robustness tests. First, all main coefficients remain virtually identical when I drop provincial fixed effects and include measures of provincial Urbanization, Landholding Concentration (Gini Index), and Unrest (the number of labor protests in the last 05 years), to account for societal pressures at the local level (results presented in the Appendix A1). The only significant control is Unrest, which ceteris paribus decreases the odds of making a good choice. This result supports the notion that labor demands might drive MCs to support or oppose electoral reforms, regardless of their electoral consequences.

As an additional robustness test, I restricted the sample to those MCs who were in the chamber by virtue of being reelected. In this way, I only consider those MCs for whom reelection was a conceivable possibility, and those for whom the

\footnotetext{
17 It is also possible that absences are a better proxy for information gathering for MCs from farther districts.

${ }^{18}$ I don't present additional models considering abstentions negative votes because those votes-if used-could have been used to stop the reform. Therefore, abstentions were functionally positive votes.

19 The variable is not statistically significant in model 09 , which includes experience fixed effects and a control for magnitude and congruence.
} 
codification of the dependent variable should most probably be expected to be valid. Results using abstentions as positive votes are unchanged when the sample is restricted. In fact, associations become stronger when using the restricted sample 20 .

Table 05. Sample restricted to reelected MCs (1912)

\begin{tabular}{cc}
\hline & Model B \\
& Correct (abstentions =yes) \\
\hline Log Distance & $-.08^{* * *}$ \\
& $(.02)$ \\
(Avg) Absent & $-8.48^{* *}$ \\
& $(2.8)$ \\
Log Distance X (Avg) Absent & $1.31^{* *}$ \\
& $. .45)$ \\
Year of election (>1910 $=1)$ & $-.42^{* * *}$ \\
Experience FE & $.10)$ \\
Num. Obs. & Yes \\
R2 & 27 \\
Estimation & .61 \\
\hline
\end{tabular}

Source: Dataset_Figueroa.

Note: The sample excludes MCs who were absent in all sessions, including the day of the nominal vote, and also those who died before the first election. (Robust standard errors in parentheses). ${ }^{*} \mathrm{p}<0.1,{ }^{* *} \mathrm{p}<0.05,{ }^{* * *} \mathrm{p}<0.01$.

Results are also very similar when the sample excludes MCs who opposed the reform (models reported in the Appendix A2), thereby only including those who made the worst possible decision (supporting a rule that did not get them reelected). Overall, results seem to closely support an account of strategic success based on the availability of local level information.

\section{Conclusions}

If electoral reforms are strategic decisions, then information should play an important role. When deciding whether to support or oppose an electoral reform, actors must assign reelection probabilities to a finite set of alternative future scenarios. However, although the decision to reform electoral laws is national in nature, information about predictable consequences is located at the local level, where elections take place.

20 Nevertheless, these results should be interpreted with caution, because no coefficient is statistically significant when abstentions are excluded ( $N=20$, results not reported). 
In the absence of developed communication systems, MCs from farther districts face greater problems for gathering local information. In order to get the information they need, they must travel to their districts-missing congressional sessions-or rely on same-district co-partisans for information sharing. But local information gathering comes at a price. In order to travel to their districts, MCs have to miss (often important) floor meetings and national information. Nevertheless, local information is more valuable than national information.

When the time comes to vote for electoral reforms, MCs with better information make better decisions: they support reforms that are favorable for them or oppose reforms that damage their reelection probabilities. Empirical evidence on Argentina's electoral reform in 1912 supports my theoretical expectations.

This article makes two contributions to the literature on regime choice miscalculation. First, it considers information as a matter of degree and allows for variance of available information among actors. Furthermore, instead of picturing the ruling elite as unified, this is portrayed as consisting of a multitude of reelection-seeking individuals; thereby providing microfoundations for bad strategic choices, without relying on a strong party-discipline assumption.

Future research could apply the theory developed in this article to other institutional settings. General theories of transitions or electoral reforms might benefit from incorporating uncertainty and information supply as explanatory variables. Methodologically, better measures of electoral success under reformed rules should be developed. This is a challenging task, as it would imply a kind of counterfactual analysis, which is hard to support empirically. The electoral reform and democratic transition agendas would both benefit from a way of quantifying the electoral consequences of reforming (or not reforming) electoral rules.

Revised by Cabo Verde Submitted in December 2014 Approved in July 2015

\section{References}

AMORIN NETO, Octavio and COX, Gary W. (1997), Electoral Institutions, Cleavage Structures and the Number of Parties. American Journal of Political Science. Vol. 41, № 01, pp. 149-174. 
ANDREWS, Josephine T. and JACKMAN, Robert (2005), Strategic Fools: Electoral Rule Choice Under Extreme Uncertainty. Electoral Studies. Vol. 24, № 01, pp. 65-84.

BARZACHKA, Nina S. (2014), When Winning Seats is not Everything: Tactical SeatLoss During Democratization. Comparative Politics. Vol. 46, № 02, pp. 209-229.

BAWN, Kathleen and ROSENBLUTH, Frances (2003), Coalition Parties vs Coalition of Parties. How Electoral Agency Shapes the Political Logic of Costs and Benefits. Unpublished Manuscript. Yale University.

BENTON, Allyson L. (2013), The Territorial Logic of Electoral Manipulation in an Electoral Authoritarian Regime: The Case of Mexico. Unpublished Manuscript. CIDE.

BIRCH, Sarah (2003). Electoral Systems and Political Transformation in PostCommunist Europe, New York: Palgrave MacMillan. 212pp.

BOIX, Carles (1999), Setting the Rules of the Game: the Choice of Electoral Systems in Advanced Democracies. American Political Science Review. Vol. 93, № 03, pp. 609-624.

BOTANA, Natalio (1985), El Orden Conservador. Buenos Aires: Editorial Sudamericana. 345pp.

CALVO, Ernesto (2009), The Competitive Road to Proportional Representation. World Politics. Vol. 61, № 02, pp. 254-295.

CALVO, Ernesto (2014), Legislator Success in Fragmented Congresses in Argentina: Plurality Cartels, Minority Presidents, and Lawmaking. New York: Cambridge University Press. 214pp.

CANTÚ, Francisco (2014), Identifying Irregularities in Mexican Local Elections. American Journal of Political Science. Vol. 58, № 04, pp. 936-951.

CASTRO, Martin (2012), El Ocaso de la República Oligárquica. Buenos Aires: Edhasa. 392pp.

COX, Gary W. (1997), Making Votes Count. Cambridge: Cambridge University Press. 339pp.

CUSACK, Thomas; IVERSEN, Torben and SOSKICE, David (2007), Economic Interests and the Origins of Electoral Systems. The American Political Science Review. Vol. 101, №03, pp. 373-391.

CUSACK, Thomas; IVERSEN, Torben and SOSKICE, David (2010), Coevolution of Capitalism and Political Representation: The Choice of Electoral Systems. The American Political Science Review. Vol. 104, № 02, pp. 393-403. 
EDMOND, Chris (2013), Information Manipulation, Coordination, and Regime Change. Review of Economic Studies. Vol. 80, № 04, pp. 1422-1458.

GODIO, Julio (2000), Historia del Movimiento Obrero en Argentina 1870-2000, Buenos Aires: Ediciones Corregidor. 1259p.

HALPERÍN DONGHI, Tulio (1992), Clase Terrateniente y Poder Político en Buenos Aires (1820-1930). Cuadernos de Historia Regional. Vol. 05, № 15, pp. 11-45.

HALPERÍN DONGHI, Tulio (2007), La Formación de la Clase Terrateniente Bonaerense. Buenos Aires: Prometeo. 210pp.

HORA, Roy (2001), The Landowners of the Argentine Pampas. Cambridge: Cambridge University Press.

IVERSEN, Torben and SOSKICE, David (2006), Electoral Institutions and the Politics of Coalitions: Why Some Democracies Redistribute More Than Others. American Political Science Review. Vol. 100, № 02, pp. 165-181.

KATZ, Richard (2002), The Internal Life of Parties. In: LUTHER, Kurt R. and MULLER-ROMMELL, Ferdinand (eds.), Political Parties in the New Europe. New York: Oxford University Press, pp. 87-118.

KREUZER, Marcus (2010), Historical Knowledge and Quantitative Analysis: The Case of the Origins of Proportional Representation. The American Political Science Review. Vol. 104, № 02, pp. 369-392.

LARREGUY, Horacio; OLEA, Cesar E. Montiel and QUERUBIN, Pablo (2014), The Role of Labor Unions as Political Machines: Evidence from the Case of the Mexican Teachers' Union. Unpublished Manuscript. Harvard University and New York University.

LEHOUCQ, Fabrice (2003), Electoral Fraud: Causes, Types, and Consequences. Annual Review of Political Science. Vol. 06, № 01, pp. 233-256.

LUPU, Noam and RIEDL, Rachel B. (2012), Political Parties and Uncertainty in Developing Democracies. Comparative Political Studies. Vol. 46, № 11, pp. 1339-1365.

MARTINEZ-BRAVO, Monica (2014), The Role of Local Officials in New Democracies: Evidence from Indonesia. American Economic Review. Vol. 104, № 04, pp. 1244-87.

MYERSON, Roger B. (1993), Effectiveness of Electoral Systems for Reducing Government Corruption: A Game Theoretical Analysis. Games and Economic Behavior. Vol. 05, pp. 118-132.

PEREYRA, Horacio J. (1999), La Reforma de la Ley Electoral del Año 1902: Proyecto de Joaquín V. González. Sociohistórica. Vol. 06, pp. 11-51. 
PERSSON, Torsten; TABELLINI, Guido and TREBBI, Francesco (2003), Electoral Rules and Corruption. Journal of the European Economic Association. Vol. 01, pp. 958-989.

PERSSON, Torsten and TABELLINI, Guido (2003), Economic Effects of Constitutions. Cambridge, MA: MIT Press. 320pp.

PERSSON, Torsten; ROLAND, Gerard and TABELLINI, Guido (2007), Electoral Rules and Government Spending in Parliamentary Democracies. Quarterly Journal of Political Science. Vol. XX, pp. 01-34.

PRIVITELLIO, Luciano de (2006), Representación Política, Orden y Progreso: la Reforma Electoral de 1902. Política y Gestión. Vol. 09, pp. 1-29.

ROKKAN, Stein (1970), Citizens, Elections and Parties. New York: David McKay Co. 470pp.

RIKER, William H. (1982), The Two-Party System and Duverger's Law: An Essay on the History of Political Science. American Political Science Review. Vol. 76, pp. 753-766.

RUNDLETT, Ashlea and SVOLIK, Milan W. (2014), Deliver the Vote! Micromotives and Macrobehavior in Electoral Fraud. Unpublished Manuscript. University of Illinois at Urbana-Champaign.

SABATO, Hilda (2004), La Política en las Calles. Entre el Voto y la Movilización. Buenos Aires 1862-1880. Quilmes: Universidad de Quilmes. 304pp.

SCHVETSOVA, Olga (2003), Endogenous Selection of Institutions and Their Exogenous Effects. Constitutional Political Economy. Vol. 14, № 03, pp. 191212.

SIMPSER, Alberto (2013), Why Governments and Parties Manipulate Elections: Theory, Practice, and Implication. New York: Cambridge University Press. 273pp.

TAAGEPERA, Rein and SHUGART, Mathew (1989), Seats and Votes: The Effects and Determinants of Electoral Systems. New Heaven: Yale University Press. xviii +292 pp.

WILKINSON, Steven (2004), Votes and violence: electoral competition and ethnic riots in India. Cambridge: Cambridge University Press. 312pp.

ZARAZAGA, Rodrigo S. J. (2014), Brokers Beyond Clientelism: A New Perspective Through the Argentine Case. Latin American Politics And Society. Vol. 56, № 03, pp. 23-45.

ZIBLATT, Daniel (2008), Does Landholding Inequality Block Democratization? A Test of the 'Bread and Democracy' Thesis and the Case of Prussia. World Politics. Vol. 60, № 04, pp. 610-641. 